STATE OF ALASKA

DEPARTMENT OF NATURAL RESOURCES

DIVISION OF GEOLOGICAL \& GEOPHYSICAL SURVEYS

\author{
Tony Knowles, Governor \\ John T. Shively, Commissioner \\ Milton A. Wiltse, Director and State Geologist
}

2000

This DGGS Report of Investigations is a final report of scientific research. It has received technical review and may be cited as an agency publication.

Report of Investigations 2000-1D

Reconnaissance engineering-geologic map of the Sagavanirktok B-1 Quadrangle, eastern North Slope Alaska

by D.S. Pinney 


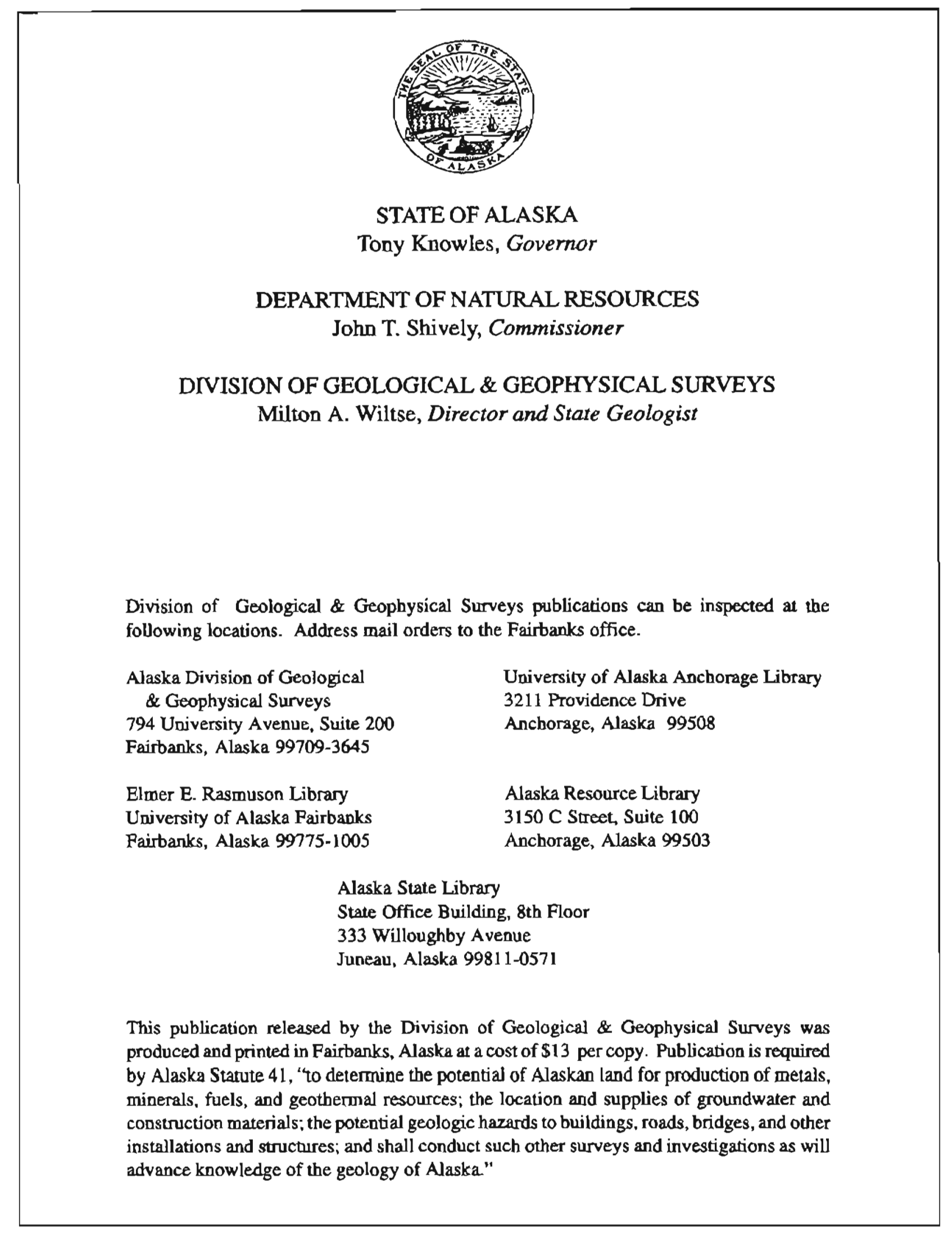




\section{CONTENTS}

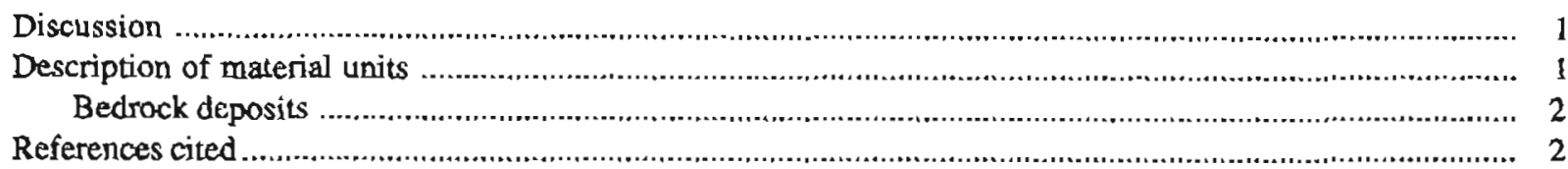

\section{SHEET}

Reconnaissance engineering-geologic map of the Sagavanirktok B-1 Quadrangle, eastern North Slope Alaska

Research supported by the U.S. Geological Survey, National Cooperative Geologic Mapping Program, under USGS award \#99HQAG0121. The views and conclusions contained in this document are those of the authors and should not be interpreted as necessarily representing the official policies, either expressed or implied, of the U.S. Government. 


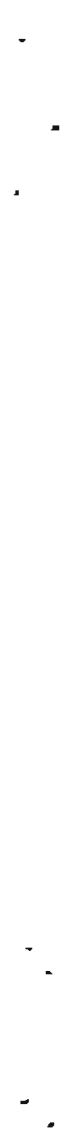

$\because$ 


\title{
RECONNAISSANCE ENGINEERING-GEOLOGIC MAP OF THE SAGAVANIRKTOK B-1 QUADRANGLE, EASTERN NORTH SLOPE ALASKA
}

\author{
by \\ DeAnne S. Pinney ${ }^{1}$
}

\section{DISCUSSION}

This map ilustrates potential near-surface sources of various geologic materials that may be useful for construction. Field observations indicate that each geologic unit (for example, strean alluvium) bas a definite composition or range of composition. Therefore, the probable presence of materials is interpreted from the distribution of geologic units on the geologic map of these quadrangles. This map is generalized and is not intended to show exact locations of specific materials. The purpose is to indicate general areas that deserve consideration for certain materials and to eliminate other general areas from consideration for these materials. Local variations are common, especially near unit boundaries.

Potential uses of map units are qualitatively summarized in tables 1 and 2 , which show potential availability of various construction materials in each engineering-geologic unit. Precise economic evaluations of specific deposits as sources of construction materials will require detailed exarnination of each deposit, including areal extent, volume, grain-size variation, thickness of overburden, thermal state of the ground (ground temperature), and depth to water table as well as logistical factors, demand, and land ownership.

This map also addresses some of the principal hazards and engineering considerations that may be associated with mapped geologic units based on their general physical properties, conditions that are characteristic of their depositional environment, and topography. Potential geologic hazards directly relate to surficial-geologic units because (1) the processes that fonned the deposits may be hazardous where still active, (2) postdepositional conditions (like ground ice) may present additional hazards, and (3) materials characteristically present in the deposits are known to be susceptible to certain bazards (like liquefaction). In general, natural bazards in lowlands are related to a lack of bearing strength (such as saburated, organic-rich swamp deposits and thawing of ice-rich permafrost) and to seasonal flooding. In highlands, mass movements may be a serious local concern. Local, unevaluated factors affecting mass movement (rock avalanches, landslides, and debris flows) include sediment textures, bedrock structures, and water content. This map is intended only as a general guide to some common hazards that may be present, depending on other factors like topography and water content, and does not preclude the presence of other unevaluated or site-specific hazards.

This map was derived electronically from the geologic map of the area (Reifensrubl and others, 2000) using Geographic Information System (GIS) software. It is only locally verified by ground observations during brief field visits. The results should be considered reconnaissance in nature.

\section{DESCRIPTION OF MATERIALS UNITS}

\section{UNCONSOLIDATED MATERIALS}

GS Fluvial and glaciofluvial gravel, sand, and silt. Chiefly (estimated $>80$ percent) clean sand and gravel. Grain size, sorting and degree of stratification are variable. Permafrost may be present, especially in older deposits. Older deposits may contain highly weathered clasts and thus may not be suitable as construction materials. Rare oversized materials may include boulders. Includes primarily GP and GW of the Unified Soil Classification (Wagner, 1957).

GM Poorly- to moderately well-sorted ciay, silt, sand, gravel, and diamicton of colluvial, fluvial and glacial origins. Includes angular, unsorted talus debris and chaotically deformed colluvium derived from landslides. Engineering applications vary widely due to large range of grain size and sorting properties. Commonly frozen. Estimated 20-80 percent coarse, granular deposits with considerable oversized material. Includes primarily GC and GM of the Unified Soil Classification (Wagner, 1957).

\footnotetext{
IAlaska Division of Geological \& Geophysical Surveys, 794 University Ave., Suite 200, Fairbanks, Alaska, 99709-3645.

Email for D.S. Pinney: deanne@dnr,state.ak,us
} 


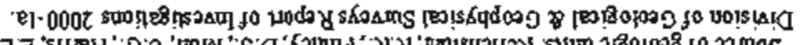

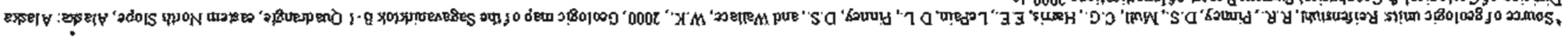

- -

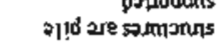

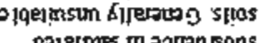

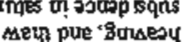

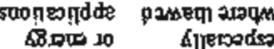

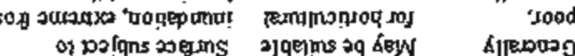

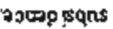

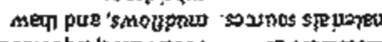
sนd

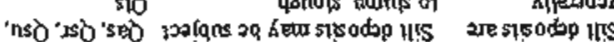

$\operatorname{sod}$

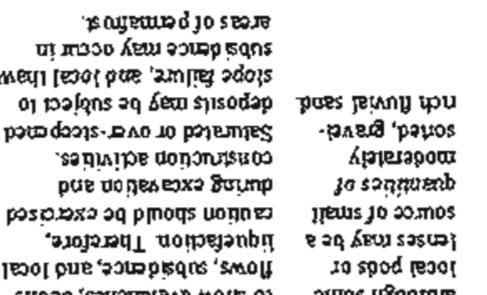

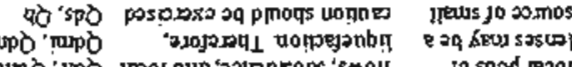

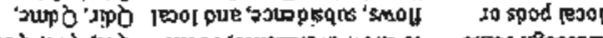

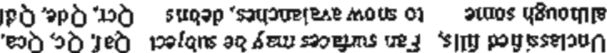

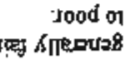

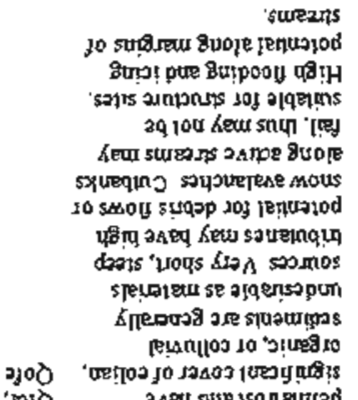

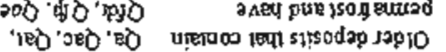

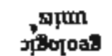

coppexponos

Maunoting

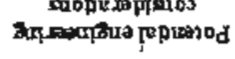

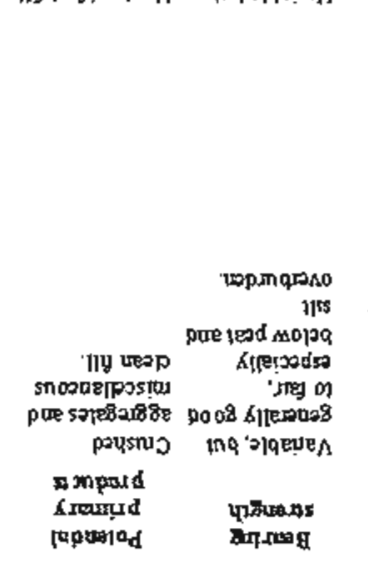

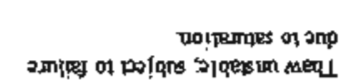

PODEAms

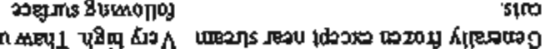

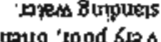

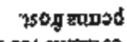

पpH-20! sul

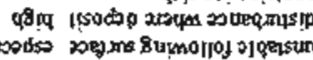

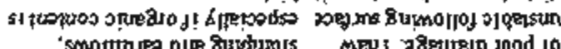

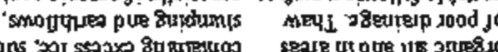

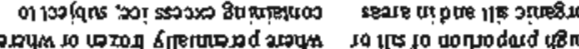

गपच

28 erser pon!lा jo sease

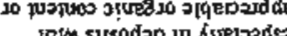

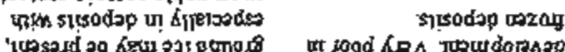

2423s

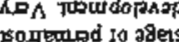

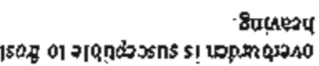
э.

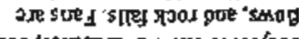

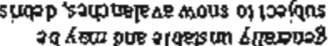

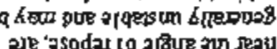
ग0 petanto

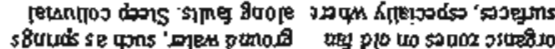

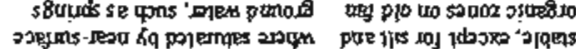

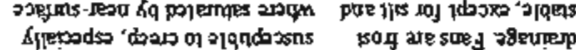
Cepols

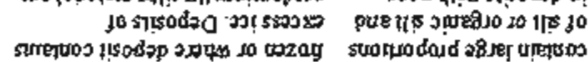

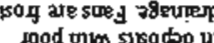

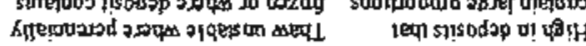

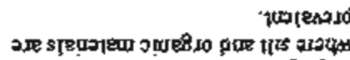

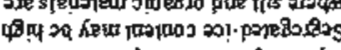

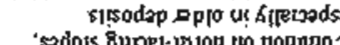

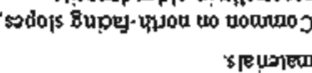

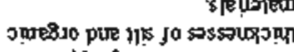

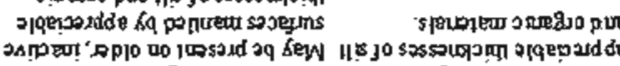

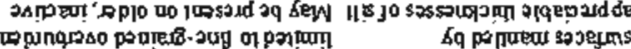

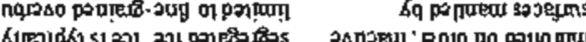

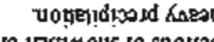
10 1pumbus jo spotcen

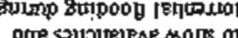

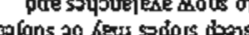
काo

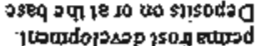

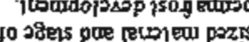

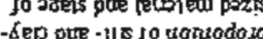

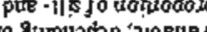

mingos

pides pur au zdtunis on polquis aq

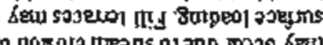

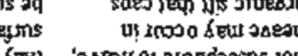

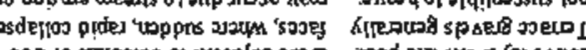

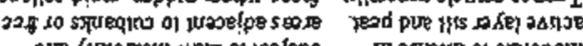
penco

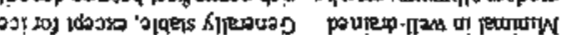

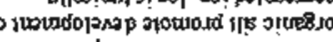
pपe Gq Lq प7

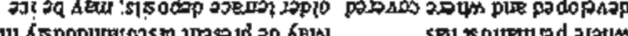

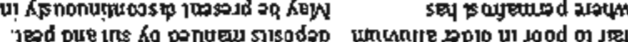
Tp po

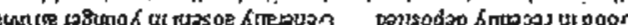

(monsode persut pure

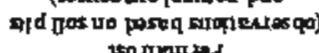
t5atounted

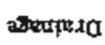

गुपm 
Table 2. Engineering propenies of bedrock units

\begin{tabular}{|c|c|c|c|}
\hline Map unit & Principal rock characteristics & Potential primary products & Component geologic units \\
\hline $\mathrm{BC}$ & $\begin{array}{l}\text { Medium-jointed, fine- } 10 \text { coarse- } \\
\text { grained sedimentary carbonate rocks. }\end{array}$ & $\begin{array}{l}\text { - Dimension stone } \\
\text { - Ornamental stone } \\
\text { - Crushed rock } \\
\text { - Cement }\end{array}$ & PMlu, PMlm, Trs \\
\hline BM & $\begin{array}{l}\text { Medium-jointed, fine- to medium- } \\
\text { grained quarzose sedimentary rocks. }\end{array}$ & $\begin{array}{l}\text { - Riprap and drain rock } \\
\text { - Crushed rock } \\
\text { - Unclassified fills }\end{array}$ & $\mathrm{Kkb}, \mathrm{Xkm}$ \\
\hline 80 & Other lithologies. & $\begin{array}{l}\text { - Unclassified fills } \\
\text { - Serpentinite may be suitable as an } \\
\text { omamental stone }\end{array}$ & $\begin{array}{l}\text { KJk, Kphu, Kc, Mkt, Mky, Mll, } \\
\text { Pe, pM, TKp, Tri, Trik, Tru, }\end{array}$ \\
\hline
\end{tabular}

Source of geologic units: Reifenstuhl, R.R., Pinney, D.S., Null, C.G., Harnis, E.E., LePain. D.L., Pinney, D.S., and Wallace, W.X., 2000, Geologic map of ure Sagavariksok B-I Quadrangle, easiem Norh Slope, Alaska: Alask a Division of Geological \& Geophysical Surveys Report of Lnvestigations 2000 -I a.

SM Silt deposited primarily by wind and reworked by fluvial and colluvial processes. May be organic rich. Commonly frozen and ice-rich, especially on north-facing slopes. Chiefly fine materials. Estimated $>80$ percent silt, sand, and clay. Includes primarily ML, MH, and SM of the Unified Soil Classification (Wagner, 1957).

OR Organic-rich silt and peat in bogs and thaw lake basins. Commoniy frozen and ice-rich due to the excellent insulating properties of peat. Generally water-saturated. Chiefly organic materials. Estimated $>50$ percent peat, organic sand, or organic silt. Includes Pt of the Unified Soll Classification (Wagner, 1957).

\section{BEDROCK MATERIALS}

BC Medium-jointed, fine- to coarse-grained sedimentary carbonate rocks. Includes limestone, and dolostone.

BM Medium-jointed, fine- to medium-grained quartzose sedimentary rocks, Includes quartzose sandstone and conglomerate, quartzite, and chert.

BO Rocks of mixed lithology and very fine-grained sedimentary lithologies that are generally poorly suited for use as construction materials. Includes shale, siltstone, graywacke and argillite.

\section{REFERENCES CITED}

Reifenstuhl, R.R., Pinney, D.S., Mull, C.G., Harris, E.E., LePain, D.L., and Wallace, W.K., 2000, Geologic map of the Sagavanirktok B-1 Quadrangle, eastern North Slope, Alaska: A laska Division of Geological \& Geophysical Surveys Report of Investigations 2000-1a., 1 sheet, scale 1:63,360.

Wagner, A.A., 1957, The use of the Unified Soil Classification Sysem by the Bureau of Reclamation: Proceedings, 4th International Conference on Soil Mechanics and Foundation Engineering (London), vol. I, p. 125. 